\title{
A Study of Hospital Waste Generation and Management Practice in Akure, Nigeria
}

\author{
Babatola, J.O.
}

\begin{abstract}
This study was carried out in Akure, the capital of Ondo State, Nigeria to assess the current practice of hospital wastes management, the magnitude and variety of wastes and the awareness of the stakeholders on the implications of their activities. The composition of wastes found in the 20 healthcare facilities visited included garbage, syringes, swabs, gauze, pads, sharps, paper, glass materials, plastics and allied, clothing materials, wastewater with blood traces and the likes. The results revealed that there is no uniform practice of hospital waste management among the hospitals studied. The study recommended that there should be source segregation of waste within each hospital as all wastes are often mixed in the same waste basket. It further recommended that government and the relevant agents should be at alert to their responsibilities of regulating the waste management practices among the hospitals in the city.
\end{abstract}

Key words: Diagnosis, Hospital, Infectious wastes, Generation, Segregation, Management, Pathogenic organisms.

\section{Introduction}

Waste can generally be described as any material lacking direct value to the user and so must be disposed of. The production of waste material is known as the waste stream and includes the entire variety of refuse generated during domestic, industrial, construction and commercial processes. Depending on the industrial base, litter is likely to vary from country to country. In highly developed countries [HDCs], the major components of industrial waste are blast furnace and steel slag, and power station ash. Food manufacturing processes and horticulture also contribute to high volumes of industrial waste. Municipal refuse is the litter originating from urban areas, houses etc. 
Although organic waste- ranging from garden detritus to food scrapsis still the leading component of municipal waste, it accounts for only a relatively small fraction of total waste production and can be personally controlled. Nevertheless, in the absence of appropriate intervention measures, disposal is likely to pose crisis in many of the world's developing countries in the not too distant future. (Ogunlowo, 1991).

On the other hand, hospital waste is waste generated during the diagnosis, treatment, or immunization of human beings or animals or in research activities in these fields or in the production or testing of biologicals. It may include wastes like sharps, disposables, anatomical waste, cultures, discarded medicines, chemical wastes, etc. These are in the form of disposable syringes, swabs, bandages, body fluids, human excreta, etc. This waste is highly infectious and can be a serious threat to human health if not managed in a scientific and discriminate manner. It has been roughly estimated that of the $4 \mathrm{~kg}$ of waste generated in a hospital at least $1 \mathrm{~kg}$ would be infected. (Ogunlowo, 1991).

\section{Waste in Nigeria}

Poor management of Nigeria's environment is costing the nation roughly US\$5 billion annually. Much of the damage results from oil and gas extraction in the Niger Delta region, poor agricultural practices, oil exploration, oil spills, grazing and habitat destruction. (Christen, 1996). Grievances over environmental management have contributed to years of instability in the oil-rich Niger Delta region of Nigeria, Africa's biggest oil producer. Figures from the World Bank suggest that US\$3 billion of the losses arose from land degradation while deforestation accounts for US\$2 billion a year.

Nigeria is spearheading the New Partnership for African Development [NEPAD]; the initiatives proposed might be great for Africa if acted upon. However, for many living in Lagos- Nigeria's former capital waste disposal remains a contentious issue, and with no end in sight. 
Refuse is thrown onto roadways, spread on pedestrian walkways or even dumped into gutters. The problem becomes compounded during the rainy season; water, no longer flowing freely along the gutters, remains stagnant, creating the necessary conditions for mosquitoes and vector borne diseases like malaria (Coker et al, 1998). It became so bad that a pragmatist approach was adopted requiring residents to spend the last Saturday morning - each month - cleaning their property; and the refuse to be placed on the streets for collection. This of course does not always happen and the rubbish piles up (Sangodoyin, 1995).

The World Health Organization, [WHO] has stated that of waste collected and sampled, 85 per cent is non-hazardous or general, about 10 per cent is infectious and 5 per cent is hazardous. Meanwhile, the World Health Organization has ranked Lagos, a Nigerian city as the dirtiest city in the world. (WHO, 2004).

Hospital waste can be defined as material, containing pathogens in sufficient concentrations or quantities that, if exposed, can cause diseases. This includes waste from surgery and autopsies on patients with infectious diseases. The words used to describe "infectious waste" are various. The terms used include: bio-hazardous waste, biological waste, medical waste, hospital waste, medical hazardous waste, infective waste, microbiological waste, pathological waste, and red bag waste. The industry also struggles with the acceptable definition of infectious waste. The regulatory agencies are not in complete agreement when defining medical waste but one can conclude from the recommendations that the following are classified as infectious waste: "human blood and blood products, cultures and stocks of infectious agents, pathological wastes, contaminated sharps, contaminated laboratory wastes, contaminated waste from patient care, discarded biological, contaminated animal carcasses, body parts, and bedding, contaminated equipment and miscellaneous infectious wastes" (Reinhardt, 1992). 
Pathological waste, usually of human origin includes tissues, organs, and body parts removed during surgery or autopsy (Hall, 1989). Blood and blood products are generally thought to be very hazardous since we identify the transmission of the HIV and HBV viruses with blood. Pathological waste must be transformed before it can be sent away to the landfill to prevent the sanitation workers from having contact with humans' parts in the dumpster.

Sharps are waste materials, which could cause the person handling it, a cut or puncture of skin e.g. needles, broken glass, saws, nail, blades, scalpels. Sharps represent a special hazard due to their ability to prick and contaminate someone who is handling them (Block, 1988). Contaminated sharps include hypodermic needles and syringes, intravenous needles, scalpel blades, lances, disposable pipettes, capillary tubes, microscope slides and cover slips and broken glass. So, it is suggested that all sharps be placed in rigid, puncture-resistant containers or recapped and stored in a special safety box kept considerably out of reach of unauthorized staff (Hershkowitz, 1990). Sharps are collected and then decontaminated by either incineration or steam sterilization. If they are steam sterilized, the sharps must be ground or crushed (Cointreau, 1997).

Hazardous wastes are those that are majorly generated in the laboratory and contain toxic substances. Industrial and hospital waste is considered hazardous as they may contain toxic substances. Certain types of household waste are also hazardous. Hazardous wastes could be highly toxic to humans, animals, and plants, are corrosive, highly inflammable, or explosive; and react when exposed to certain things for example gases. Hospital waste contaminated by chemicals used in hospitals is considered hazardous. These chemicals include formaldehyde and phenols, which are used as disinfectants, and mercury, which is used in thermometers or equipment that measure blood pressure (Halbwichs, 1994). Most hospitals in Akure do not have proper disposal facilities for these hazardous wastes. These 
include drugs and chemicals that are returned from wards, spilled, outdated, contaminated, or are no longer required.

\section{Materials and Methods}

The preliminary part of this section involved collection of general information about the hospitals like the size/type of the hospital, year operation started, patronage, number of staff, type of services, position/age of respondent and sex. Classification of hospitals was done under three categories: according to available infrastructure for example number of beds and other available services as large, medium and small; according to ownership as Government, Private or Missionary and according to other purposes, for example educational orientation as primary, secondary, or tertiary. Twenty (20) hospitals were selected to give a variety of sampling options. The hospitals were located all over the Akure metropolis and included big, small, government-owned and private hospitals. They were divided into zones with respect to proximity to one another to ease transportation costs; oral interviews were then conducted to fill the questionnaires from which data would be taken.

The wastes which the researcher got access to were put in a polythene bag, weighed and then recorded after each section was visited. In one department of some hospitals some waste types were not available for weighing as they were already disposed of due to lack of proper storage means. Placements are given to the families, body parts and tissues are either flushed into the sewer or buried.

Medical wastes could be highly infectious and delicate to handle thus some precautions were taken to prevent infection and contribution of some diseases that could be caused by piercing of body by sharps that have not been segregated, inhalation of fumes and contact with harmful pathogens and germs. Precautions taken include

- Wearing overalls and aprons to protect the clothing and body;

- Wearing gloves and forceps in handling; 
- Wearing surgical masks to prevent inhalation of poisonous fumes; and

Finally disinfection of waste before any kind of contact was done with either JIK or DETTOL but more often, JIK is used because of its strong and corrosive nature, proving to be a serious killer of germs and pathogens

A proper inventory of the waste systems was carried out with questions that bring out information on how waste is collected, treated and disposed. The nature of waste, its volume, method of disposal, the section from which it comes and precautions taken in the handling, if taken at all were part of information collected. This section was interactive and not done only by researchers but also by respondents to the questionnaire who are professionals like doctors, nurses or nonprofessionals like refuse or waste handlers.

The data collected were coded onto a spreadsheet and then transformed into easily understandable charts and tables to be discussed further on in this paper.

\section{Results Analysis and Discussion}

The waste composition studied is part of the continuing effort to measure and understand the waste generated in hospital clinics in Akure and in Nigeria in general. The composition study is based on field sorting events around hospitals/clinics in Akure main town. The waste samples were analyzed and survey data was compiled and managed so as to enable the estimation of waste generation qualities and management practices. Table 1 clearly shows the average waste generation by waste type and the estimated number of beds in each of the twenty hospitals/clinics visited in Akure.The government owned hospital and missionary owned hospital and clinics generated more waste than the privately owned ones, though there are more privately owned hospitals/clinics than the government and missionary owned hospitals/clinics put together. 
Figure 1 showed the waste generation rate in percent of all the sections of the hospitals. It was observed from the study that the highest volume of waste generated is from the patient rooms/wards. Intensive Care Unit was not available in any of the hospitals/clinics as at the time of this study. It would be observed that the least volume of waste generated is from the x-ray/scan rooms. From Fig.1, we see that the patients' rooms were the major sources of the highest volume of waste in all the hospitals. From the general consideration of $75 \%$ general waste, $20 \%$ infectious and 5\% hazardous, Table 2 below which covered all the hospitals under study was obtained.

\section{Waste Type}

For simplicity in data representation, waste type generated from hospitals/ clinics were classified into the following types: general, infectious and hazardous. Figure 2 shows the generation rate of the classes of waste. Infectious waste refers to all waste suspected to contain pathogens for example used needles, gloves, drain tubes, cotton gauzes, swabs, body parts. Hazardous wastes are capable of causing hazard such as cuts and injuries; they include waste like sharps, broken sample bottles. General wastes include all wastes that are neither infectious nor hazardous. It was observed that out of the total waste generated in hospitals/clinic an average of $75 \%$ of it was classified as general waste while $20 \%$ as infectious and the $5 \%$ left as hazardous.

\section{Waste Handling and Level of Awareness}

All twenty mission-owned hospitals/clinics visited were using unperforated waste bins with lids. Also from data collected we found out that only about $2 \%$ of the staff who handle waste was trained to do so. Most of these people were between the ages of 35 and 60. This has contributed immensely to poor or no segregation of different type of hospital waste, with general infectious waste often mixed in the same primary source. We found that there is insufficient awareness of the magnitude of hospital waste management issue by concerned 
individuals at different level from directors or divisional heads to waste pickers.

\section{Waste Segregation}

Based on the data in Table 1, it was discovered that $65 \%$ of hospitals/clinics do not segregate waste generated in their clinics. However, $30 \%$ do segregate infectious waste as recorded. Waste segregation is the only key step to hospital waste management. Unlike in other developing countries, waste segregation is virtually not being carried out in Nigeria. The composition study is based on field sorting events around hospitals/clinics in Akure main town. The waste samples were analyzed and survey data was compiled and managed so as to enable the estimation of waste generation qualities and management practices. Table 3 clearly shows the average waste generation by waste type and the estimated number of beds in each of the twenty hospitals/clinics visited in Akure. The government owned hospital and missionary owned hospitals and clinics generated more than the government and missionary owned hospitals/clinics put together.

Table 3 clearly showed the average waste generation by waste type and the estimated number of beds in each of the twenty hospitals/clinics visited in Akure. The government owned hospital and missionary owned hospitals and clinics generated more than the government and missionary owned hospitals/clinics put together.

\section{Precautions Taken In Waste Handling}

This aspect also created worries as it was discovered that basic processes like sterilization of disposal equipment and autoclaving were not done due to cost and the unavailability of an autoclave machine, which was available only in Banjo Memorial Hospital. The precautionary measures adopted in the hospitals studied were as follows: All twenty hospitals were divided into eleven sections/departments for easy study. They are: 
Patient rooms/wards, Male wads/rooms, Female wards/rooms, Children ward/rooms, Emergency/Treatment rooms/Out Patient Department, Operating rooms/Theatre, Delivery rooms, Intensive Care Units (not available in the 20 hospitals), Nurses Floor Station, X-ray and Scan Rooms, Laboratory/Test Rooms.

\section{Disposal Methods}

A variety of disposal methods were used by different hospitals with landfilling being the commonest however not in a proper practice and open dumps surprisingly highly unutilized in many hospitals. The summary of the findings are presented in Figure 4.

\section{Conclusion and Recommendations}

\section{Conclusion}

The study covered the generation and prevailing methods of hospital waste management as being practiced by the hospitals in Akure metropolis. It was revealed from this study that hospital wastes in most hospitals are treated in a like manner as the general wastes. The findings of this study revealed that only about $35 \%$ of the hospitals studied segregate their wastes. Even though sanitary landfills are mostly used by the majority of the hospitals as a means of final disposal, however the current practice does not follow the recommended standards. The current practice among the hospitals and clinics in Akure shows that neither the government nor other regulatory agencies is closely monitoring the management of hospital waste to ensure adherence to recommended standards.

\section{Recommendations}

Based on the findings of this study, it is recommended first and foremost that every hospital should be compelled to adhere to the internationally recommended standards for hospital waste management. The hospital supporting staff needs to be educated about the inherent danger of improper handling of hospital wastes as some of them are hazardous to human health. Government and the relevant agents should be at alert to their responsibilities of regulating the 
waste management practices among the hospitals in the city. Owing to the importance of this study, further work is recommended to be carried out to assess the impacts of the current practice on the immediate environment of the hospitals.

\section{References:}

Block, S.S. (1977). Disinfection, Sterilization and Preservation. 2nd edition. U.S.A : Lea and Febiger.

Christen, J. (1996). Solid Waste Management in Developing Countries. Sweden: Icon Publishers.

Cointreau, S.J (1997). Waste Issues: Urban Problems. England: Lowden Publications.

Coker, A.O, Ogunlowo, O.O. and Sangodoyin, A.Y. (1998). Managing Hospital Waste in Nigeria. 24th WEDC Conference: Sanitation and Water for All

Halbwichs, H. (1994). Solid Waste Disposal in District Health Facilities. World Health Forum 15 363-367

Hall, S.K. (1989). Infectious Waste Management: A Multifaceted Problem. Journal of Pollution Engineering 21 (8), 74 -78

Hershkowitz, A. (1990). Without A Trace: Handling Medical Wastes Safely. Technology Review, 93(6)35-40.

Holmes, J. (1988). Environment and Development in Latin America: The Politics of Sustainability. England: Manchester University Press.

Reinhardt, G. (1992). Feasibility Report on Hazardous Waste Management in African Cities, Volume 1.

Sangodoyin, A.Y. (1995). Assessment of the adequacy of by-plant monitoring. International Journal of Environmental Studies, 48, 257 $-262$.

World Health Organization, (WHO) (2004). Waste in Developing Countries.

\section{Acknowledgement}

The author expresses sincere gratitude to Messrs Sekobe C.and Elusogbon S.O who assisted so much in the field work in the course of this work 
Table1. Daily Waste Generation (kg/day) and the Numbers of Beds in Each Hospitals/Clinics

\begin{tabular}{|l|l|l|l|l|l|}
\hline $\mathrm{S} / \mathrm{N}$ & $\begin{array}{l}\text { Names of Hospitals and } \\
\text { Clinics in Akure }\end{array}$ & $\begin{array}{l}\text { No of } \\
\text { beds }\end{array}$ & General & $\begin{array}{l}\text { Infectiou } \\
\text { s }\end{array}$ & Hazardous \\
\hline 1 & State Specialist Hospital & 110 & 13.055 & 3.48 & 0.87 \\
\hline 2 & Optimum Clinic & 8 & 4.2 & 1.12 & 0.28 \\
\hline 3 & City Hospital & 8 & 3.6 & 0.96 & 0.24 \\
\hline 4. & Royal Medical Center & 6 & 2.55 & 0.68 & 0.17 \\
\hline 5 & Don Bosco Health Center & 4 & 2.775 & 0.74 & 0.185 \\
\hline 6 & St John and Mary Hospital & 10 & 7.65 & 2.04 & 0.51 \\
\hline 7 & Sijuwade Specialist Hospital & 12 & 3.975 & 1.06 & 0.265 \\
\hline 8 & St Michael Hospital, Pol. HQ & 10 & 3.975 & 1.0 .6 & 0.265 \\
\hline 9 & Banjo Memorial Hospital & 30 & 2.45 & 0.66 & 0.165 \\
\hline 10. & Adetade Hospital, Ondo Rd & 10 & 1.875 & 0.5 & 0.125 \\
\hline 11 & First Mercy Hospital,Gbogi & 42 & 14.071 & 3.92 & 0.98 \\
\hline 12 & FUTA Gate Clinic & 4 & 4.05 & 1.08 & 0.27 \\
\hline 13 & Oludare Hospital, Fanibi & 12 & 11.755 & 3.14 & 0.785 \\
\hline 14 & Abitoye Hospital, Ijapo & 22 & 2.926 & 0.78 & 0.195 \\
\hline 15 & University Health Centre & 6 & 4.5 & 1.2 & 0.3 \\
\hline 16 & Faith Clinic Oke Aro & 6 & 1.95 & 0.52 & 0.13 \\
\hline 17 & Abitoye Hospital, Ijoka & 15 & 0.75 & 2.6 & 0.65 \\
\hline 18 & Crown Hospital & 17 & 10.725 & 2.86 & 0.715 \\
\hline 19 & Hope Hospital, Ijoka & 6 & 3.225 & 0.86 & 0.25 \\
\hline 20 & Momaak Specialist Hospital & 10 & 4.65 & 1.24 & 0.31 \\
\hline
\end{tabular}


Table 2 Waste Generation by Waste type

\begin{tabular}{|l|l|l|l|l|}
\hline Hospital & $\begin{array}{l}\text { Total waste/ } \\
\text { day } \\
\text { (kg) }\end{array}$ & \multicolumn{4}{l|}{ Daily Waste Generation (kg/ day) } \\
\hline & & General (75\%) & Infectious (20\%) & Hazardous (5\%) \\
\hline Optimum & 5.6 & 4.2 & 1.12 & 0.28 \\
\hline City & 4.8 & 3.6 & 0.96 & 0.24 \\
\hline Don Bosco & 3.7 & 2.78 & 0.74 & 0.18 \\
\hline Royal & 3.4 & 2.55 & 0.68 & 0.17 \\
\hline St. Mary and John & 10.2 & 7.65 & 2.04 & 0.51 \\
\hline Sijuwade & 6.6 & 4.95 & 1.32 & 0.33 \\
\hline St. Michael & 5.3 & 3.975 & 1.06 & 0.265 \\
\hline Banjo & 3.3 & 2.475 & 0.66 & 0.165 \\
\hline Adetade & 2.5 & 1.875 & 0.5 & 0.125 \\
\hline First Mercy & 19.61 & 14.708 & 3.922 & 0.981 \\
\hline FUTA Gate & 5.4 & 4.05 & 1.08 & 0.27 \\
\hline Oludare & 15.7 & 11.775 & 3.14 & 0.785 \\
\hline Abitoye & 3.9 & 2.925 & 0.78 & 0.198 \\
\hline FUTA Health Centre & 6.0 & 4.5 & 1.2 & 0.3 \\
\hline Faith & 2.6 & 1.95 & 0.52 & 0.13 \\
\hline Abitoye (Ijoka) & 13.0 & 9.75 & 2.6 & 0.65 \\
\hline Crown & 14.3 & 10.725 & 2.86 & 0.715 \\
\hline Hope Clinic & 4.3 & 3.225 & 0.86 & 0.215 \\
\hline Momeak & 6.2 & 4.65 & 1.24 & 0.31 \\
\hline State Hospital & 17.4 & 13.05 & 3.48 & 0.87 \\
\hline & & & & \\
\hline
\end{tabular}

Table 3: Level of Adoption of Segregation Method in the Twenty Hospitals/Clinics

\begin{tabular}{|c|l|}
\hline $\begin{array}{c}\text { Number of } \\
\text { hospital/clinics }\end{array}$ & Segregation method adopted \\
\hline 6 & Segregate infectious waste only \\
\hline 1 & $\begin{array}{l}\text { Segregate infectious, hazardous and } \\
\text { biodegradable waste }\end{array}$ \\
\hline 13 & Do not segregate waste \\
\hline
\end{tabular}


Babatola, J.O.

Figure 1: Average Waste generation per section

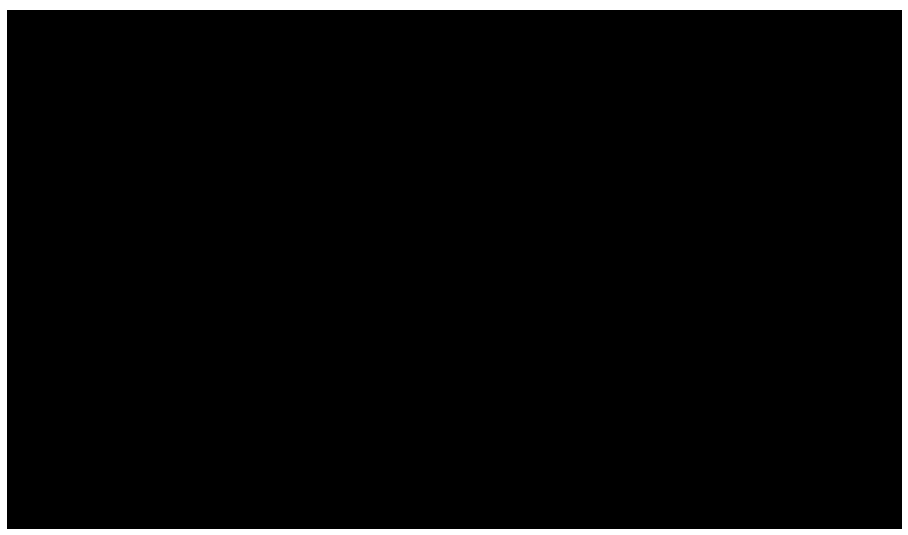

A- Patient rooms; B- Emergency rooms; C- Operating rooms; D- Delivery rooms; E- ICU, F- Nurses section; G- X ray; H- Laboratory

Figure 2: Waste Component Expressed in Percentages

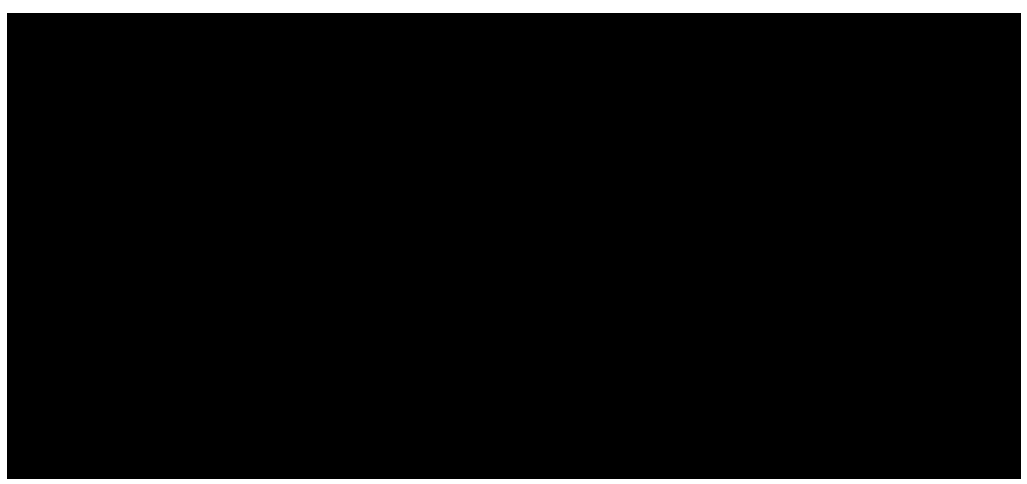


Fig.3 Precautionary Measures in Practice

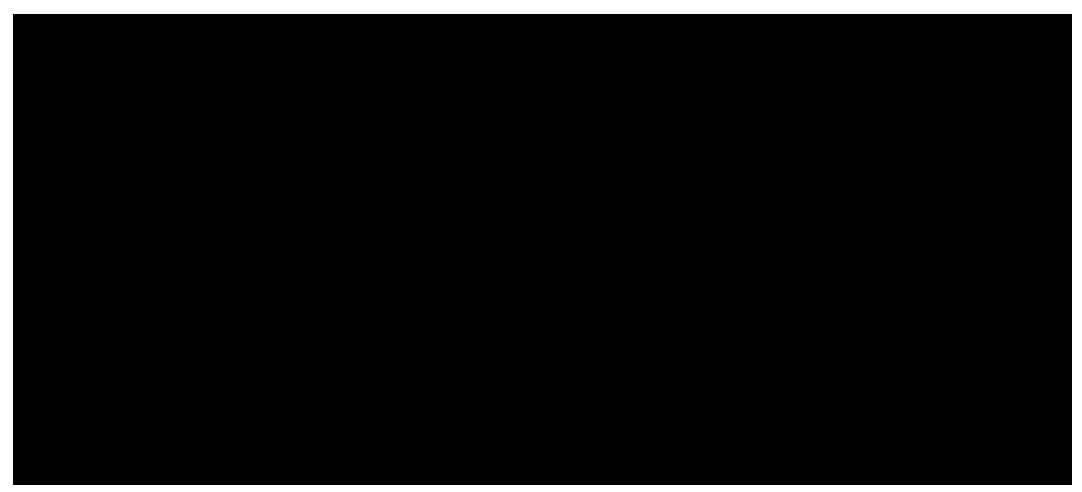

$\mathrm{A}=$ Those that use gloves only; $\mathrm{B}=$ Special measures according to nature of wast, $\mathrm{C}=$ Use gloves, nose masks only; $\mathrm{D}=$ use overalls/ information/gloves/

Figure 4: Analysis of Disposal Methods

Key: A- Landfilling; B- On site burial; C- Incineration; D- Open dumps; E- Open burning 